\title{
Co-Evolusi Antibiotik dalam Pola Penggunaan Antibiotik menurut Pendekatan Teori Jaringan-Aktor
}

\author{
Decky Ferdiansyah \\ Badan Perencanaan Pembangunan Daerah (Bappeda) Provinsi Lampung \\ email: dqapt2@gmail.com
}

\section{Abstrak :}

Ancaman resistensi antibiotik menjadi isu hangat yang selalu menarik untuk dibahas. Terlebih lagi pola penggunaan antibiotik yang semakin tidak terkendali membuat isu resistensi antibiotik menjadi kekhawatiran dari waktu ke waktu. Di satu sisi, butuh waktu yang sangat lama dan biaya yang tidak sedikit untuk menemukan sebuah antibiotik, namun di sisi lain beberapa bakteri juga semakin resisten terhadap antibiotik. Seolah ada pertandingan kejar-mengejar antara antibiotik dan bakteri. Teori Jaringan-Aktor atau Actor-Network Theory (ANT) merupakan teori pada bidang studi ilmu sosial, sains dan teknologi. Terdapat empat konsep dasar dalam teori ANT ini yaitu : aktor, jaringan, translasi dan intermediari. Bila penggunaan antibiotik dalam pengobatan dianalisis menggunakan teori ANT, maka akan didapati beberapa hal menarik untuk diamati. Bahwa keputusan untuk menggunakan atau tidak menggunakan antibiotik tidak sepenuhnya berada di tangan manusia penggunanya. Terjadinya co-evolusi pada antibiotik dan bakteri dalam tubuh manusia inilah yang menjadi kekhawatiran banyak pihak dan menjadi alasan bagi WHO untuk mengkampanyekan World Antibiotic Awareness Week 2017.

Keyword : Co-evolusi antibiotik, WHO, resistensi, Teori Jaringan-Aktor

\section{Pendahuluan}

Pada tanggal 13 - 19 November 2017, World Health Organization (WHO) meluncurkan kampanye World Antibiotic Awareness Week 2017 atau Pekan Kesadaran Antibiotik Dunia 2017.

Pada kegiatan ini, WHO mengajak beberapa stakeholder seperti pemerintah, tenaga profesional kesehatan, industri, organisasi kemasyarakatan dan lain-lain untuk bersama-sama mengkampanyekan kesadaran penggunaan antibiotik.

Beberapa langkah telah dilakukan melalui seminar, media sosial, cerita sukses, kuis interaktif dan bentuk kegiatan kampanye lainnya agar terwujud peningkatan kesadaran masyarakat dunia akan bahayanya resistensi antibiotik dan langkah apa saja yang diperlukan untuk menghindarinya.

Di Indonesia, WHO melibatkan Kementerian Kesehatan RI dan Ikatan Apoteker Indonesia (IAI) untuk bersama-sama mengkampanyekan Pekan Kesadaran Antibiotik Dunia 2017.

Ancaman resistensi antibiotik menjadi isu hangat yang selalu menarik untuk dibahas. Terlebih lagi pola penggunaan antibiotik yang semakin tidak terkendali membuat isu resistensi antibiotik menjadi kekhawatiran dari waktu ke waktu. 
Di satu sisi, butuh waktu yang sangat lama dan biaya yang tidak sedikit untuk menemukan sebuah antibiotik, namun di sisi lain beberapa bakteri juga semakin resisten terhadap antibiotik. Seolah ada pertandingan kejar-mengejar antara antibiotik dan bakteri. Siapa yang lebih cepat?

\section{Sejarah antibiotik}

Antibiotik adalah segolongan molekul, baik alami maupun sintetik, yang mempunyai efek menekan atau menghentikan suatu proses biokimia di dalam organisme, khususnya dalam proses infeksi oleh bakteri.

Penggunaannya dikhususkan untuk mengobati infeksi yang disebabkan oleh bakteri. Karena itulah, antibiotik tidak tepat digunakan untuk pengobatan terhadap infeksi yang disebabkan oleh virus, jamur dan benda asing lainnya selain bakteri.

Penemuan antibiotik terjadi secara tidak sengaja pada tahun 1928 ketika seorang ilmuwan Skotlandia yang bernama Alexander Fleming lupa membersihkan sediaan bakteri pada media dalam sebuah cawan petri dan meninggalkannya selama beberapa hari.

Ketika akan membersihkan cawan tersebut, ia menemukan sebagian jamur telah tumbuh pada media tersebut dan sebagian lain telah bersih dari bakteri yang sebelumnya ada.

Didasari oleh ketertarikannya pada fenomena tersebut, ia melakukan penelitian lebih lanjut dan menemukan bahwa jamur yang tumbuh tersebut adalah Penicillium chrysogenum atau sejenis jamur berwarna biru muda. Lalu ia melakukan ekstraksi terhadap jamur tersebut dan hasil ekstraknya adalah sebuah antibiotik alami pertama, yaitu Penicillin G.

\section{Pendekatan Patofisiologis}

Dalam memahami penyakit dan penyembuhannya, seorang tenaga kesehatan biasa menggunakan pendekatan patofisiologi manusia, yaitu ilmu kesehatan interdisiplin yang mempelajari perubahan fisiologis manusia akibat penyakit.

Patofisiologi disebut ilmu interdisiplin dalam keilmuan kesehatan dikarenakan merupakan integrasi dari ilmu anatomi, fisiologi, biologi molekuler, mikrobiologi, genetika dan farmakoterapi.

Pendekatan interdisiplin diperlukan agar lebih tepat dalam memahami penyebab penyakit dan pilihan pengobatan yang paling sesuai. Namun, apakah pendekatan patofisiologi adakah pendekatan interdisiplin satu-satunya? Adakah pendekatan lain yang dapat digunakan dalam memahami relasi penyakit dan penyembuhannya?

\section{Actor and Networking Theory : Konsep dan Perkembangannya}

Teori Jaringan-Aktor atau Actor-Network Theory (ANT) merupakan teori pada bidang studi ilmu sosial, sains dan teknologi. Teori ini awalnya digagas dan dikembangkan oleh Bruno Latour, Michel Callon dan John Law pada tahun 1980-an.

Pada awalnya, teori ANT ini hanya dipakai pada bidang keilmuan Science and Technology Studies (STS), namun dalam perkembangannya teori ANT menjadi populer sebagai alat analisis dalam berbagai bidang di luar STS, seperti analisis organisasi, geografi, sosiologi, ekonomi, antropologi bahkan kesehatan. 
Perkembangan yang pesat ini telah menempatkan teori ANT menjadi sebuah metadisiplin dalam bidang keilmuan STS. Disebut metadisiplin dikarenakan merupakan sebuah integrasi baru dalam suatu keilmuan yang berkembang dari pendekatan multi dan interdisiplin.

Terdapat empat konsep dasar dalam teori ANT ini yaitu : aktor, jaringan, translasi dan intermediari. Para penggagas Teori ANT berpendirian bahwa suatu entitas sosial berisi unsur (aktor) manusia dan non-manusia yang bersama-sama membentuk relasi, translasi dan intermediari dalam sebuah jaringan yang saling terkait.

Jaringan yang saling terkait ini tidak hanya berfokus pada relasi sosial antar aktor manusia, tetapi mencakup juga aktor non-manusia (obyek/artefak teknik).

Semua aktor ini, baik manusia maupun non manusia, berperan dalam membentuk dan memelihara sebuah jaringan yang heterogen. Dalam jaringan yang terbentuk ini juga terjadi penjajakan dan penyesuaian aksi-aksi (translasi) serta sirkulasi yang berlangsung antar-aktor (intermediari) sampai akhirnya tercapai suatu relasi dan jaringan yang stabil.

Proses relasi, translasi dan intermediari yang terjadi dalam sebuah jaringan dan melibatkan antar aktor manusia dan non-manusia harus terjadi agar terpeliharanya keutuhan dan kestabilan jaringan. Walaupun pada akhirnya jaringan yang telah terbentuk kemudian akan membentuk jaringan baru lagi dengan proses yang sama. Begitu seterusnya.

Dalam proses-proses yang terjadi dalam suatu jaringan diperlukan prinsip asimetri umum, dimana hal-hal yang diberlakukan pada aktor manusia juga diberlakukan pada aktor nonmanusia. Bahwa aktor non-manusia dalam jaringan juga dapat melakukan proses relasi, translasi maupun intermediari.

Hal ini tidak berarti bahwa teori ANT menganut faham dehumanisasi, namun prinsip ini diperlukan agar analisis terhadap jaringan yang terbentuk dapat lebih menyeluruh. Tentu saja pada hakikatnya aktor manusia memiliki aspek kehendak dan kemampuan kognitif yang membedakannya dengan aktor non-manusia.

Persis ketika kita mendefinisikan relasi antar teknologi dan manusia. Kehendak menusia merupakan kekuatan utama untuk menggerakkan proses kognitif mental sehingga menghasilkan pengetahuan serta aktifitas tubuh.

Aktifitas ini yang pada akhirnya akan mentransformasikan unsur-unsur material menjadi teknologi. Dengan kata lain, teknologi adalah obyek bentukan dari kehendak, pengetahuan dan aktifitas manusia. Namun, penggunaan berbagai obyek bentukan tersebut dapat membawa implikasi transformasi pada anggota tubuh dan pancaindra manusia. Hal ini pada gilirannya akan mempengaruhi proses kognitif dan kehendak manusia (Mitcham, 1994)

\section{Tinjauan Penggunaan Antibiotik dalam Perspektif Actor-Networking Theory}

Bila penggunaan antibiotik dalam pengobatan dianalisis menggunakan teori ANT, maka akan didapati beberapa hal menarik untuk diamati. Bahwa keputusan untuk menggunakan atau tidak menggunakan antibiotik tidak sepenuhnya berada di tangan manusia penggunanya (baca : pasien). 
Ada aktor manusia lainnya yaitu tenaga kesehatan seperti dokter dan apoteker. Pada kondisi eksisting, hanya ada relasi awal yang terjadi antara pasien (aktor manusia) dan bakteri (aktor non-manusia), sehingga terjadilah infeksi dalam tubuh manusia. Relasi yang terjadi ini tentu saja tidak membuat nyaman bagi pasien, sehingga kemudian pasien memutuskan mendatangi dokter untuk berobat agar memperoleh kesembuhan.

Diagnosa yang menjadi kewenangan dan kompetensi dokter merupakan tahap awal dalam keputusan pemilihan antibiotik. Ada infeksi bakteri tertentu, maka antibiotik tertentu juga yang harus digunakan.

Pada tahap ini pasien tidak memiliki pilihan lain, karena dokter memiliki kewenangan dan kompetensi atas keputusan penggunaan antibiotik. Sehingga pada tahap ini, muncul relasi baru antara pasien - dokter dan pasien - resep. Relasi baru ini belum memutus relasi sebelumnya antara pasien dan bakteri.

Pada tahap berikutnya ketika dokter memberikan resep dan pasien menebus resep tersebut di apotek, muncul aktor manusia baru yang bernama apoteker. Terbentuklah relasi baru antara pasien dan apoteker.

Pada tahap ini, ketika resep sudah ditebus dan obat sudah diserahkan kepada pasien, muncul kembali aktor non-manusia baru yang bernama antibiotik. Sehingga selain terjadi relasi antar aktor manusia (pasien dan apoteker) dan terjadi relasi antara aktor manusia dan non-manusia yaitu pasien - antibiotik.

Pada tahap lanjutan ini akan terbentuk sebuah kompleksitas relasi. Namun kompleksitas relasi ini belum dapat dikatakan sebagai sebuah jaringan yang stabil.

Perlu proses bagi antibiotik yang dikonsumsi oleh pasien agar dapat bekerja sesuai dengan kur pengobatannya, sehingga muncullah relasi baru antara antibiotik dengan bakteri.

Tepat ketika antibiotik dapat membunuh bakteri pada tubuh pasien sehingga menimbulkan kesembuhan, maka terputuslah relasi pasien dengan bakteri. Sehingga terbentuklah jaringan yang stabil dan terpelihara oleh aktor manusia (pasien, dokter, apoteker) dan aktor non-manusia (bakteri dan antibiotik) yang ada dalam jaringan tersebut. Inilah tahap akhir pembentukan jaringan.

Dalam teori ANT, jaringan yang terbentuk dari cerita relasi di atas masih dapat dikembangkan lagi dikarenakan dapat terjadi co-evolusi atau perubahan bersama baik pada aktor manusia maupun pada aktor non-manusia.

Pemilihan dan penggunaan antibiotik yang tidak tepat diagnosa dan tepat penggunaan oleh pasien, akan menimbulkan ketidakstabilan pada jaringan yang sudah terbentuk sehingga dalam jangka waktu tertentu akan menyebabkan terjadinya resistensi bakteri.

Antibiotik yang seharusnya memiliki khasiat untuk membunuh bakteri menjadi berkurang potensinya dan di sisi lain bakteri yang semestinya "terbunuh" dengan antibiotik menjadi kebal atau resisten. Dengan kata lain, penggunaan antibiotik yang tidak tepat, dengan dosis dan cara yang juga tidak tepat akan mengakibatkan bakteri kebal terhadap antibiotik. 
Kebalnya antibiotik tersebut tentu saja terjadi dalam tubuh manusia/pasien yang juga memberikan respon secara fisiologis terhadap fungsi antibiotik dan resistensi bakteri. Dalam pendekatan teori ANT, kondisi ini dapat disebut sebagai co-evolusi atau perubahan bersama.

Terjadinya co-evolusi pada antibiotik dan bakteri dalam tubuh manusia inilah yang menjadi kekhawatiran banyak pihak dan menjadi alasan bagi WHO untuk mengkampanyekan World Antibiotic Awareness Week 2017. Mudah-mudahan memberikan penyadaran bagi kita semua.

Daftar Pustaka :

https://en.wikipedia.org/wiki/Pathophysiology/

Latour, Bruno. 2005. Reassembling The Social : An Introduction to Actor-Network Theory. Oxford University Press. New York

Mitcham, Carl. 1994. Thinking Through Tecnology : The Path Between Engineering and Philosophy. The Chicago University Press. Chicago

Yuliar, Sonny. 2009. Tata Kelola Teknologi : Perspektif Teori Jaringan-Aktor. Penerbit ITB. Bandung

www.who.int/campaigns/world-antibiotic-awareness-week/en/ 